Walisongo Law Review (Walrev), Vol 1 No. 2 (2019)

DOI: 10.21580/Walrev/2019.1.2.5213

Copyright (C) 2019 Walisongo Law Review (Walrev)

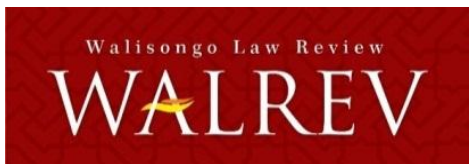

\title{
Incoming Extradition in Indonesia and Its Implication to Human Rights
}

\author{
Efendi Lod Simanjuntak \\ Afiliasi: Universitas Diponegoro, Semarang \\ e-mail: eldanalegal@gmail.com
}

\begin{abstract}
Law enforcement to transnational fugitives especially those perpetrators of money laundering with international dimension in Indonesia, in particular related to incoming extradition is needed to reconstruct. This is because hitherto, the decision to extradite is the decision of the executive branch as stipulated in Act No.1 of 1979 on Extradition. Hence, the consideration for the government to extradite is more on political concern rather than judicial. This practice is deemed neglecting the protection of human rights and creating legal uncertainty, especially in relation to detention period that could exceed beyond admissible time as stipulated in KUHAP because of the grace period on the issuance of the Presidential Decision. This research is doctrinal and field study. Based on findings in the field, incoming extradition request must be based on the court's decision, or judicial order in the future to ensure protection of human rights and legal certainty of the person who is subject of the extradition and to the requested country.
\end{abstract}

Penegakan hukum terhadap buronan transnasional, terutama para pelaku pencucian uang di Indonesia, perlu sebuah rekontruksi 
khususnya terkait dengan ekstradisi. Ini karena sampai sekarang, keputusan untuk mengekstradisi adalah keputusan cabang eksekutif sebagaimana diatur dalam Undang-Undang No.1 tahun 1979 tentang Ekstradisi. Oleh karena itu, pertimbangan bagi pemerintah untuk mengekstradisi lebih pada masalah politik daripada peradilan. Praktik ini dianggap mengabaikan perlindungan hak asasi manusia dan menciptakan ketidakpastian hukum, terutama dalam kaitannya dengan masa penahanan yang dapat melebihi melampaui waktu yang dapat diterima sebagaimana diatur dalam KUHAP karena masa tenggang pada penerbitan Keputusan Presiden. Penelitian ini bersifat doktrinal dan studi lapangan. Berdasarkan temuan di lapangan, permintaan ekstradisi yang masuk harus didasarkan pada keputusan pengadilan, atau perintah pengadilan di masa depan untuk memastikan perlindungan hak asasi manusia dan kepastian hukum dari orang yang menjadi sasaran ekstradisi dan ke negara yang diminta.

Keywords: extradition; executive order; extradition; human rights.

\section{Introduction}

One of the fundamental aspects relating to extradition request in Indonesia is the placement of decision regarding extradition as executive order (Pemerintah RI, 1979). It means that the final decision of extradition request particularly incoming extradition in Indonesia is fully on the hand of President as chief executive. Because such decision is not a judicial order, there is a trend that whether the incoming extradition request is accepted or not which is more based on the consideration of President's political than that of law. This practice tends briefly to consider aspects of human rights because an opportunity is not often given to a person to be extradited in order to make a legal remedy to its decision of extradition and the existing judicial order only as consideration unbinding President.

On the other hand, the uncertainty of law regarding period of the issued Presidential Decree regarding incoming extradition is not occurred. There is a certain determination relating to how long a person to be extradited will 
receive Presidential Decree. This matter is often implicated in the detention period of the suspect or fugitive which is longer than the detention period provided in the Code of Criminal Procedure (KUHP). The detention period which is longer than the detention period provided in such Code of Criminal Procedure is clearly a violation against Human Rights.

The extradition issues are actually juridical issues although this matter cannot be separated from the political issues. The instrument of extradition up to a certain level is even debated frequently in either legal or political instrument (Pemerintah RI, 1979). However, if it is observed from the substance covering the extradition, the extradition issues are actually full of juridical issues. For example, whether the crime committed by the suspect fulfills the double criminality principles, containing ne bis in idem aspect, related to political or military crime, level of different sharply penalization are found. All of these matters are juridical issues.

In the discussion of extradition issues, we are surely talking about a person who is a fugitive in the foreign jurisdiction for the crime committed in the Requesting State. A person who is a fugitive in Indonesian territory for a crime in other states will give authority to the legal authority in Indonesia to arrest and repatriate the person concerned to the state in which the crime is committed. This matter is made based on an official extradition request to Indonesia. Whether extradition request will be accepted or rejected, it fully depends on presidential consideration.

Human Right problems and certainty aspect of law relating to the incoming extradition in Indonesia is essential to be in question. This matter relates to no time limit for President to issue the Presidential Decree on Extradition and President is not also bound to the existing judicial order, so that it does not reflect the aspect of Human Rights. Non-commitment of President to the judicial order on acceptance or rejection of such incoming extradition request keeps on confirming a trend of the most dominant political dimension or political consideration to decide the incoming extradition in Indonesia.

It's time for all of these problems to be reconstructed because no matter how the law enforcement to international-dimensioned crimes in Indonesia particularly regarding incoming extradition, Human Rights issue may not 
be ignored. The importance of Human Rights should be observed because the existence of individual is only deemed as object of the international cooperation in criminal issues to date and Human rights issues in international relationship context tend to be deemed only as national issues of the state concerned rather than international issues (Stessens, 202: 256). Even though, these Human Rights issues are universally international issues and each state is obliged to respect the Human Rights. Therefore, it is time to make an effort of reconstruction of incoming extradition in Indonesia to ensure the protection of Human Rights and certainty of law. That effort is made through a legal reform to strengthen the participation of judicial order by placing the final order on incoming extradition to be a domain of the judicial order rather than as executive order.

\section{Discussion}

Issues relating to the incoming extradition around the world are generally full of Human Rights issues. A person escaping into a foreign country and to be a fugitive in an incoming jurisdiction is possibly caused by a usual crime or other issues such as political dispute, war or rebellion and other causes. A person to be fugitive in other countries because of political dispute, such person generally has status as asylum seeker. The asylum seeker should be traditionally protected. Giving a political asylum to foreigner escaping because of political issues is deemed as expression of state sovereignty (Standbrok, 2000: 3). However, those discussed in this writing are transnational crime actors deliberately escaping from avoiding a lawsuit in which the crime is committed (fugitives from justice). Therefore, the law enforcement over the fugitive handed to the requesting state to be judged later becomes relevant because each person committing crime should be principally handed to the requesting state or judged by the state in which the actor hides in accordance with "aut punere aut dedere" principle (Starke, 1989: 470).

When a fugitive is caught in a foreign territory or incoming jurisdiction, such person can be extradited to the requesting state as state having criminal jurisdiction to the actor (Vienna Convention 1988). However, a fugitive to be extradited remains to have rights to fight back the extradition 
act. This matter is important as a part of respect for Human Rights in which a fugitive has the right to access to justice as a part of respect for Human Rights particularly relating to the incoming extradition in Indonesia.

Human Rights issues are often deemed as domestic issues of the requesting state to date. Rights of fugitive are often deemed only as object of international cooperation. This matter encouraging the European Human Right Court confirms that violation against human rights on International cooperation is never allowed (Stessens, 2000: 256).

This Human Right matters to be necessary highlighted relates to the uncertainty of law regarding a waiting period of the issued Presidential Decree on extradition. In Law No. 1 of 1979 regarding Extradition nothing is mentioned in connection with how long that Presidential Decree will be published or issued. In certain cases, the person to be extradited has been put in jail for years without the time limit of detention. Even though based on the provisions of Code of Criminal Procedure for the detention respectively 40 days (investigation), 60 days (District Court), 60 days (High Court), and 60 days (the Supreme Court, so that total detention period including its extension is not more than 400 days. For the period of detention exceeding this provisions the prisoner should be of course freed for the sake of law (Code of Criminal Procedure).

In the case of Sayeed Abbas Azad bin Sayed Abdul Hamid (Pemerintah RI, 2005) it appears that from this Australian fugitive has been arrested by Indonesian Immigration on July 31, 2009 to extradition on August 13, 2015 to Australia it needed 6 (six) years, or at least from the issued Judgment of the District Court of South Jakarta in 2013 to this fugitive extradited to Australia on August 13, 2015 it needed the period of detention for 2.205 days (Interpol.go.id).

Likewise, in the case of the fugitive Lim Yong Nam, Singaporean wanted by the United States of America, from arrested on October 23, 2014 to the issued judgment of District Court of Batam (PN Batam, 2015) on April 20, 2015 to the issued Presidential Decree No.3 of 2016 on February 01, 2016 deciding such fugitive to be extradited to the United Stated of America on March 31, 2016, such fugitive had been put in the jail for 507 days. 
All of these empirical facts show a violation against Human Rights which is real and contradicts to the detention period provided in the Code of Criminal Procedure, that is 400 days - from the arrest to permanent legal force (inkracht van gewijsde) (Code of Criminal Procedure). These facts show a deprivation of the suspect's rights of freedom and independence illegally and violation against Human Rights in real in the context of the inter-jurisdiction law enforcement in Indonesia (KUHAP). Even though, the arrest and detention should be made by full responsibility, taking into account morally, the detention is a ruthless act which can only be imposed to a person based on a judicial verdict.

These Human Rights issues often ignored in the context of inter-state cooperation is confirmed by the information source in Indonesian National Police Headquarter - Hubinter stating that the aspect of Human Rights in the context of inter-state cooperation through extradition or Mutual Legal Assistance (MLA) instrument and extradition should be less observed because fugitives in jail are generally more than 2 (two) years before a Presidential Decree is issued.

Observing such reality above, the incoming extradition request in Indonesia should be changed in paradigm or reconstructed. The importance of change is based on normative rules indicating that the judicial order on extradition is only advice for President to accept or reject the incoming extradition request (Pemerintah RI, 1979). The authority of President contained in the form of Presidential Decree is beschikking indicating that the authority of politic working in its decision is not based on the jurisdiction order.

Therefore, it the time to regulations in Law No. 1 of 1979 regarding Extradition stating that the extradition request is not the product of judicial order but executive order are changed. In this context, court is expected to be an institution having authority to reject or accept the incoming extradition request as well as this judicial order should bind President. With the existence of such paradigm change, international cooperation to extradite someone is expected should not reduce or sacrifice a protection of human rights (Stessens, 2000: 253). 


\section{Comparison with extradition practice in Australia}

Practice in which the court becomes interpreter to the incoming extradition request is seen in the practice of extradition in Australia. This matter is observed from the decision on extradition to several Indonesian fugitives escaping to the Kangaroo country as the fugitive Adrian Kiki Ariawan and Hendra Raharja (Tempo, 2008).

Australian Law indicates that the executive order regarding extradition can be sued to court. Extradition is a process to surrender someone to other countries to face a lawsuit or to suffer punishment or to carry out sentence determined by the Austrlian Attorney General pursuant to Section 16 Extradition Act. That decision of extradition is then investigated by Australia Magistrate to determine whether someone can be extradited or not. Decision of the Magistrate approving someone's extradition can be later opposed or sued to Federal Court or Supreme Court of a State or Territory (www.ag.gov.au).

This mechanism is obviously seen from the Indonesia experience asking extradition of the fugitive Adrian Kiki Ariawan escaping to Australia in 2010 (PT DKI, 2013). Extradition request from Indonesian Government to Australia regarding the fugitive Adrian Kiki Ariawan was approved by the Australian Minister of Justice. Approval from the Australian Minister of Justice was then sued or opposed by this fugitive in the District Court of Perth in Western Australia with the reason that the Indonesian judicial order was made without his attendance and violated against human rights of the person concerned. The Court of Perth granted Adrian Kiki Ariawan's lawsuit by annulling the Australian Ministerial Decree of Justice. This case continued to the level of Supreme Court of Western Australia then strengthening judgment of the District Court of Perth. However, at the cassation level of High Court of Australia, Adrian Kiki Ariawan's objection was rejected by strengthening decision of Australian Government to extradite the person concerned to Indonesia.

In the case of the fugitive Hendra Rahardja, who also escaped to Australia obviously appears that decision of Australian Government to the extradition concerned to Indonesia was sued in the court. Initial extradition request from Indonesia to Australia began from an event on June 1999 
when Hendra Rahardja was detained by the Australian Federal Police at the request of the Indonesian National Police through an assistance of the Interpol. Hendra Rahardja at that time in Sidney Australia was alleged to have committed money laundering crime in Sidney from the money of crime committed in Indonesia. Over the detention of the Federal Police Australia, Hendra Rahardja filed objection to the court rejecting the extradition to Indonesia. However, Judgment of the Federal Court of Australia New South Wales District Registry No.N531 of 2000 dated August 1, 2000 decides to reject Hendra Rahardja's objection and decides to extradite this fugitive to Indonesia.

From here it is seen that the judgment to reject or accept the incoming extradition request in Australia formerly decided by the Australian Ministry of Justice as branch of executive may be opposed or sued to the court. This matter more reflects Human Rights. While in Indonesia, extradition request may be directly approved by Indonesian Government without a judicial process. Sometimes a judicial process is found, but a final decision should be on President's hand because the judicial order contemplated does not bind President. In other words, President as head of executive is the only the highest institution having authority to accept or reject incoming extradition or MLA request in Indonesia.

\section{Application of Reciprocity Principle in Criminal Issues}

Current transnational crime actors may operate inter-jurisdiction. Transnational criminal actors immediately may commit a crime in a state and also may escape to another jurisdiction to avoid legal prosecution. Therefore, the law enforcement to these inter-state fugitives desires a role of court relating both incoming extradition and Indonesia extradition request to out-coming extradition, keeping in mind that all this time in pursuit of fugitives abroad more relies on cooperation of inter -peace officer than that of inter-court through a formal path. This matter causes no legitimate legal basis to the state in which a fugitive hides in order to surrender the actor to the requesting state.

With reference to no legal basis it is admitted by an official of Embassy of the Republic of Indonesia in Singapore stating that the Singapore 
government may not surrender a fugitive to the requesting state if there is no evidence of judgment of the court in which it has permanent legal force proving a person's crime and legal status and in Singapore law it is known as "the rule of law". Therefore, in the future, Indonesian peace officer apparatus should be completed with a court order having function as legal basis for foreign state to surrender a fugitive.

Such court order may be deemed as legal product of judicial body of a sovereignty State so that it has a strong legitimation to be implemented in the foreign jurisdiction based on reciprocity principles. Admission and implementation of a court order to the inter-state fugitives reciprocally based on this reciprocity principle may enable the exchange of fugitives through inter-judicial cooperation although it is admitted that the issues relating to the inter-state sovereignty aspects in the framework of inter-state law enforcement often become an obstacle especially a progress of information technology often makes difficult inter-state peace officers to do the law enforcement to international fugitives (Fukuyama, 2011: 12).

Admission and implementation of a criminal judgment in foreign jurisdiction reciprocally through inter-judicial cooperation is not impossible to do this time among globalization flow and borderless states. Such cooperation has been successful in the civil matters particularly relating to foreign arbitration judgment as referred to in New York Convention 1958 (Fukuyama, 2011: 12). The foreign arbitration judgment may be admitted and implemented in the foreign jurisdiction as long as it is not on the contrary to laws and public orders of the requested state (Beaumen, 2015: 31-36). In Indonesia, the admission and implementation of the foreign arbitration are admitted as provided in Law No. 30 of 1999 regarding Arbitration and Alternative Dispute Settlement (Fukuyama: 2011: 12).

\section{Conclusion}

The incoming extradition request in Indonesia all this time has not certainty of law and does not give enough warrant of Human Rights. Cause of this matter is a decision on extradition is not the decision of judicial body but that of executive body as provided in the Explanation of Law No.1 of 1979 regarding Extradition. The result is the decision on the incoming 
extradition request tends to be more based on president's consideration of politic than consideration of jurisdiction causing suspect's rights is less observed. This normative rule has been implicated to the uncertainty of law regarding a waiting period of issue to Presidential Decree on extradition and has impact to an unlimited detention period of suspect as often occurred in practices indicating the detention period of suspect often exceeding the detention period provided in the Code of Criminal Procedure. This reality is clearly a violation against Human Rights. Therefore, in the future the incoming extradition request should be changed from on the hand of president (executive order) to be domain of judicial body.

The incoming extradition request to the out-coming extradition should be resulted in a court in order to obtain judicial order later to be functioned as legal basis for the requested state to surrender a fugitive to the requesting state. This judicial order is expected to be implemented abroad through inter-judicial cooperation in the field of criminal matters reciprocally based on reciprocity principle.

As recommendation, it is presented that in the future Indonesian national criminal policy particularly relating to the incoming extradition should be revised so that it becomes domain of the court to ensure the protection of Human Rights and certainty of law. Moreover, a certain duration of how long the Presidential Decree on extradition to be issued or accepted by the suspect should be stipulated explicitly so that there is no an unlimited detention period of the suspect. [w]

\section{Noted}

In the Explanation about Law No. 1 of 1979 regarding Extradition as it is mentioned that decision on extradition is not the product of judicial order but rather that of executive order.

Extradition request can be rejected if it relates to political, military crimes, lack of double criminality principles or gap of punishment demand in each State, etc. Read more on Article 5-17 of Law No. 1 of 1979 regarding Extradition. 
In Vienna Convention 1988 regarding Money Laundering, it mentions that the implementation of extradition should be observing domestic law of the state concerned. It means that this convention does not set aside implementation of criminal jurisdiction of the state concerned relating to extradition.

Indonesian Government to Australia is based on Presidential Decree of the Republic of Indonesia No.17 of 2015 regarding People Smuggling to Australia.

Hendra Rahardja is alleged to have committed money laundering crime in Australia in which the money is alleged from corruption crime in Indonesia performed when he served as shareholder and also commissioner of Bank Harapan Sentosa (BHS) - finally it was liquidated by Indonesian Government on November 1997. This fugitive was rumored to have passed away at the time of extradition process from Australia causing this fugitive has not been extradited to Indonesia.

New York Convention 1958 on Recognition and Enforcement of Foreign Arbitral Awards. This convention has been ratified by Indonesian Government through Presidential Decree No.34 of 1981.

Admission and Implementation of foreign judicial order in the field of civil and commercial in the European Union may be done as confirmed.

\section{Reference}

Beaumen, Paul and Lara Walker. 2015. "Recognition And Enforcement In Civil And Commercial Matters In The Brussels I Recast And Some Lessons From It And The Recent Huge Convention For Huge Judgment Project", Journal of Private International Law, 1 (11): 3163

European Court of Human Rights. 1989. Soering v. UK: ECHR

Fukuyama, Francis. 2011. The Origin of Political Order. New York: Farfar Strauss and Giroux.

Indonesian Government through Presidential Decree No.34 of 1981. 
Interview between writer and interview in Indonesian National Police Headquarter (Hubinter) on November 26, 2016

Kitab Undang-Undang Hukum Acara Pidana (KUHAP).

PN Batam (Judgment of the District Court of Batam Number: 01/Pid.Ekst/ 2015/PN.BTM)

PT DKI (Judgment of High Court) Number. 71/PID/2013/PT.DKI

Standbrook, Ivor and Stanbrook, Clive. 2000. Extradition Law and Practice. New York: Oxford University.

Starke, J.G, 1989. Pengantar Hukum Internasional, Jakarta: Sinar Grafika.

Stessens, Guy, 2002. Money Laundering, A New International Law Enforcement. UK: Cambridge University.

The interview was made by the writer in Embassy of the Republic of Indonesia in Singapore on August 23, 2016.

Undang-Undang Nomor 1 Tahun 1979 tentang Extradisi.

Undang-Undang Nomor 17 Tahun 2015

Vienna Convention 1988 regarding Money Laundering,

www.ag.gov.au

www.kejaksaan.go.id

www.interpol.go.id

www.tempo.co. 